\title{
In Vivo Pharmacokinetics and Pharmacodynamics of Positional Isomers of Mono-PEGylated Recombinant Human Granulocyte Colony Stimulating Factor in Rats
}

\author{
Jung Seok Kang and Kang Choon Lee* \\ Drug Targeting Laboratory, School of Pharmacy, SungKyunKwan University; 300 Chonchon-dong, Jangan-ku, Suwon \\ 440-746, Korea.
}

Received February 12, 2013; accepted April 9, 2013

In this study, the pharmacokinetic and pharmacodynamic properties of $\mathrm{Lys}^{35}$, Met ${ }^{\mathrm{N} \text {-terminal }}{ }^{\text {, and } \mathrm{Lys}^{17}-}$ mono-PEGylated recombinant human granulocyte colony stimulating factor (rhG-CSF) positional isomers were evaluated in rats. The in vitro biological activities of $\mathrm{Lys}^{35}$, $\mathrm{Met}^{\mathrm{N} \text {-terminal }}$, and $\mathrm{Lys}^{17}$-mono-PEGylated rhG-CSF were determined by examining NFS-60 cell proliferation. Plasma concentrations of rhG-CSF and white blood cell (WBC) counts and absolute neutrophil conunt (ANC) were measured and pharmacokinetic and pharmacodynamic properties were determined after a single subcutaneous administration of the Lys ${ }^{35}$, $\mathrm{Met}^{\mathrm{N} \text {-terminal }}$, or $\mathrm{Lys}^{17}$ isomers at $0.1 \mathrm{mg} / \mathrm{kg}$ in rats. The in vitro biological activities of $\mathrm{Lys}^{35}$, Met ${ }^{\mathrm{N} \text {-terminal }}$, and $\mathrm{Lys}^{17}$-mono-PEGylated rhG-CSF individual positional isomers were $20.1 \%, 37.4 \%$, and $15.3 \%$, respectively, that of rhG-CSF. However, all three mono-PEGylated rhG-CSF isomers had a greater blood half-life $\left(T_{1 / 2}\right)$ and in vivo efficacy as determined by WBC counts and ANC than rhG-CSF, but no significant difference

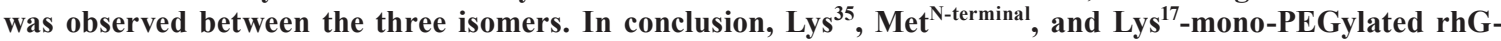
CSF individual positional isomers exhibit an enhanced the in vivo pharmacokinetics and pharmacodynamics. Furthermore, three isomers have comparable in vivo pharmacokinetic and pharmacodynamic properties, but their in vitro biological activities are PEGylation site dependent.

Key words random PEGylation; covalent conjugation; individual positional isomer; in vitro biological activity; blood half-life

PEGylation describes the chemical modification of therapeutic proteins by covalent conjugation with polyethylene glycol (PEG), a non-toxic, non-immunogenic polymer that is approved by U.S. Food and Drug Administration (FDA) for parental administration, that is used as a strategy to overcome the disadvantages associated with therapeutic proteins with a short half-life due to rapid clearance from the body. ${ }^{1,2}$ PEGylation is a well established technology and a common practice during the development of therapeutic proteins, because it prolongs serum half-life and improves the pharmacokinetics of therapeutic proteins by decreasing renal clearance and enhancing proteolytic resistance due to increased steric hindrance. ${ }^{3-6)}$

Several therapeutic proteins, such as Adagen ${ }^{\circledR}$, Oncaspar $^{\circledR}$, PEG-Intron ${ }^{\circledR}$, PEGASYS ${ }^{\circledR}$, Somavert ${ }^{\circledR}$, Neulasta ${ }^{\circledR}$, Macugen ${ }^{\circledR}$, Mircera $^{\circledR}$, Cimzia $^{\circledR}$, and Krystexxa ${ }^{\circledR}$, are conjugated by alkylation, acylation, or thiol modification. ${ }^{7,8)}$ Methoxy polyethylene glycols (mPEG) activated with aldehyde (ALD), succinimidyl carbonate (SC), $N$-hydroxy succinimide (NHS), or malaimide (MAL) are available for the specific conjugation of amino acid side chains and N-terminal amines on proteins. ${ }^{9-12)}$ mPEG activated with NHS (mPEG-NHS) is frequently used to modify amino groups of target proteins and produce stable amide linkages between PEG and primary amines, such as, $\mathrm{N}$-terminal $\alpha$-amine and/or lysine $\varepsilon$-amine residues. In most cases, when mPEG-NHS and mPEG-SC are used, PEGylation occurs randomly at multiple lysine, histidine residues, and $\mathrm{N}$-terminals in therapeutic proteins depending on reaction $\mathrm{pH}^{10,13)}$ The PEGylated therapeutic proteins using mPEG-NHS are consequently heterogeneous and in the number of individual positional isomers and/or multiple isomers that could be

The authors declare no conflict of interest.

*To whom correspondence should be addressed. e-mail: kclee@skku.edu obtained after random PEGylation. ${ }^{13,14)}$ The structural characterization of individual PEG positional isomers is a significant chemistry and manufacturing control (CMC) challenges in the manufacturing process for PEGylated therapeutic proteins. ${ }^{15)}$

We previously described the preparation of a long-acting, mono-PEGylated recombinant human granulocyte colony stimulating factor (rhG-CSF) using trimeric-structured mPEG-NHS ${ }^{16)}$ and the structural characterization of individual positional isomers isolated from mono-PEGylated rhG-CSF using a preparative two-step chromatography method developed in our laboratory. In this previous study, we demonstrated that mono-PEGylated rhG-CSF is a mixture, of three positional isomers in which PEG is linked to $\mathrm{Lys}^{35}$, Met ${ }^{\mathrm{N}-\text { terminal }}$, or Lys ${ }^{17}{ }^{17)}$ However, no report has previously described on the pharmacokinetic and pharmacodynamic properties of individual positional isomers of PEGylated proteins.

In this study, we examined the pharmacokinetic and pharmacodynamic properties of $\mathrm{Lys}^{35}$, Met ${ }^{\mathrm{N}-t e r m i n a l}$, and $\mathrm{Lys}^{17}$ mono-PEGylated rhG-CSF individual positional isomers in Sprague-Dawley rats.

\section{MATERIALS AND METHODS}

Materials rhG-CSF was obtained from the Biopharmaceuticals Production Department of Dong-A Pharm. Co., Ltd. Trimeric-structured methoxy polyethylene glycol activated with $N$-hydroxy succinimide (mPEG-NHS) was purchased from the NOF Corporation (Tokyo, Japan). All reagent grade chemicals and buffer components were purchased from Sigma-Aldrich (St. Louis, U.S.A.)

Preparation of Mono-PEGylated rhG-CSF and the Isolation of $\mathrm{Lys}^{35}$, Met ${ }^{\mathrm{N} \text {-terminal, }}$, and $\mathrm{Lys}^{17}$-Mono-PEGylated rhG-CSF Positional Isomers We previously described the 
preparation of mono-PEGylated rhG-CSF using a $23 \mathrm{kDa}$ trimeric-structured mPEG-NHS ${ }^{16)}$ and the isolation of the Lys ${ }^{35}$, $\mathrm{Met}^{\mathrm{N} \text {-terminal }}$, and $\mathrm{Lys}^{17}$-mono-PEGylated rhG-CSF positional isomers formed using a preparative two-step chromatography method developed in our laboratory. ${ }^{17)}$ The isolated Lys ${ }^{35}$, $\mathrm{Met}^{\mathrm{N} \text {-terminal }}$, and $\mathrm{Lys}^{17}$-mono-PEGylated rhG-CSF isomers were concentrated to approximately $1 \mathrm{mg} / \mathrm{mL}$ and diafiltrated with $10 \mathrm{~mm}$ sodium acetate $(\mathrm{pH} 4.0)$ containing $5 \%(\mathrm{w} / \mathrm{v})$ sorbitol, and $0.004 \%(\mathrm{w} / \mathrm{v})$ Tween 20 , and stored at $4{ }^{\circ} \mathrm{C}$ until required.

In Vitro Biological Activities of $\mathrm{Lys}^{35}, \mathrm{Met}^{\mathrm{N} \text {-terminal, and }}$ Lys $^{17}$-Mono-PEGylated rhG-CSF Positional Isomers The in vitro biological activities of the three positional isomers were determined using a cell proliferation assay using the G-CSF dependent cell line, NFS-60. ${ }^{18,19)}$ NFS-60 cells (ATCC CRL-1838) were grown in RPMI 1640 medium containing $10 \%$ fetal bovine serum (FBS) and $1 \mathrm{ng} / \mathrm{mL}$ of interleukin-3 (IL-3) in a humid $\mathrm{CO}_{2}$ incubator at $37^{\circ} \mathrm{C}$. Cells were then washed twice with phosphate-buffered saline (PBS) and resuspended at $3.5 \times 10^{5}$ cells $/ \mathrm{mL}$ in assay media (RPMI 1640 medium containing 5\% FBS). A $100 \mu \mathrm{L}$ aliquot of the prepared NFS-60 cell suspension was then plated into each well of a 96-well micro plate. rhG-CSF and the $\mathrm{Lys}^{35}$, Met ${ }^{\mathrm{N} \text {-terminal, }}$ and $\mathrm{Lys}^{17}$ isomers were prepared at a concentration of $8 \mathrm{ng} /$ $\mathrm{mL}$ and then a series of 10 twofold dilutions serially with assay media and $50 \mu \mathrm{L}$ aliquots were added to wells. After $48 \mathrm{~h}$ of incubation, cell proliferation was determined using 3-(4,5-dimethylthiazol-2-yl)-5-(3-carboxymethoxyphenyl)2-(4-sulfophenyl)-2H-tetrazolium (MTS) assay kits (Promega, Madison, WI, U.S.A.). Sample-treated NFS-60 cells in the 96-well plate were then further incubated for $2 \mathrm{~h}$ after adding $30 \mathrm{ul}$ of MTS solution per well and wells were read at $490 \mathrm{~nm}$ using an ELISA reader (TECAN, Sunrise ${ }^{\mathrm{TM}}$, Korea). The potencies of the three positional isomers were calculated using the parallel line assay (a statistical method), and results were expressed as relative activities (\%) versus rhG-CSF. Data are presented as the means \pm S.E.M.s of triplicate experiments.

Animals Male Sprague-Dawley (SD) rats (8-10 weeks old, mean weight $200 \mathrm{~g}$ ) were purchased from Orient Bio (Korea). Four groups of six rats (randomly selected) were housed individually in cages and maintained under controlled conditions $\left(21-25^{\circ} \mathrm{C} / \mathrm{RH} 40-70 \% / 12-\mathrm{h}\right.$ light and dark cycle) before and during the experiment. Food and water were provided ad libitum. All experiments were performed in accordance with the "Standard Operation Procedure for Animal Care and Experiments" (SOP-ANC) of Dong-A Pharmaceutical, and with the "Guide for the Care and Use of Laboratory Animals" published by the National Institutes of Health.

In Vivo Pharmacokinetic and Pharmacodynamic Analysis of the $\mathrm{Lys}^{35}$, Met ${ }^{\mathrm{N} \text {-terminal, }}$, and $\mathrm{Lys}^{17}$-Mono-PEGylated rhG-CSF Positional Isomers The in vivo pharmacokinetics and pharmacodynamics of the three positional isomers were studied in male SD rats. After a week of acclimation, three groups of $6 \mathrm{SD}$ rats received a single subcutaneous (s.c.) injection of the $\mathrm{Lys}^{35}$, Met ${ }^{\mathrm{N} \text {-terminal }}$, or $\mathrm{Lys}^{17}$ isomers at a dose of $0.1 \mathrm{mg} / \mathrm{kg}(1 \mathrm{~mL} / \mathrm{kg})$ and one group was s.c. administered rhG-CSF at $0.4 \mathrm{mg} / \mathrm{kg}(1 \mathrm{~mL} / \mathrm{kg})$. Two hundred microliter of blood were withdrawn from tail veins and placed in Microtainer tubes (BD, U.S.A.) containing dipotassium ethylenediaminetetraacetate $\left(\mathrm{K}_{2}\right.$ EDTA) at $0,2,4,8,12,24,48,72$, $96,120,144,168 \mathrm{~h}$ post-injection rats treated with the three positional isomers and at $0,0.2,0.4,0.6,1,1.5,3,6,8,10$, $24 \mathrm{~h}$ post-injection for rats treated with rhG-CSF and then immediately centrifuged at $12000 \mathrm{rpm}$ for $10 \mathrm{~min}$. Separated plasma was stored at $-80^{\circ} \mathrm{C}$ prior to enzyme-linked immunosorbent assay (ELISA) analysis. Concentrations of rhG-CSF in plasma samples were measured using G-CSF ELISA kits (Bender Medsystems, Austria). Individual pharmacokinetics (PK) parameters $\left(C_{\max }, T_{\max }, A U C_{\text {last }}, T_{1 / 2}, M R T_{\text {last }}\right)$ were calculated using WinNonlin software (Pharsight Inc., U.S.A.) by non-compartmental analysis. Maximum plasma concentrations $\left(C_{\text {max }}\right)$ and times to reach maximum concentrations $\left(T_{\max }\right)$ were determined directly from the data. The area under plasma concentration time curve $(A U C)$ from time zero to the last day of experiment $\left(A U C_{0-168 \mathrm{~h}}\right)$ was calculated using a standard method. ${ }^{20)}$ The first-order terminal rate constant $\left(k_{\mathrm{el}}\right)$ was measured using linear regression of the terminal log-linear decay phase. The terminal half-life $\left(T_{1 / 2}\right)$ was calculated as $\ln (2)$ divided by $k_{\mathrm{el}}$. Data are presented as means \pm S.E.M.s.

The pharmacodynamic effects of the three isomers and of rhG-CSF were assessed by measuring white blood cell (WBC) counts and absolute neutrophil counts (ANC) after a single s.c. administration with PEGylated individual positional isomers at $0.1 \mathrm{mg} / \mathrm{kg}$ and after daily s.c. administrations of rhG-CSF at $0.1 \mathrm{mg} / \mathrm{kg} / \mathrm{day}$ for $5 \mathrm{~d}$. Two hundred microliters of blood were collected from tail veins and placed in Microtainer tubes (BD, U.S.A.) containing $\mathrm{K}_{2}$ EDTA at $0,1,2,3,4,5,6 \mathrm{~d}$ after administration for the in vivo pharmacodynamic analysis. Peripheral blood WBC counts and ANC were determined using ADVIA-120 (Bayer, German). Maximum cell counts and areas under cell count $v s$. time curves $(A U C)$ for WBC counts and ANC were calculated for each treatment group. AUCs were calculated using the linear trapezoidal rule from 0 to $6 \mathrm{~d}$ postinjection. Data are presented as means \pm S.E.M.s.

Statistical Analysis Statistical analysis was carried out using SigmaStat Software (SPSS Inc., Chicago, IL, U.S.A.). The statistical significances of differences between the Lys ${ }^{35}$, $\mathrm{Met}^{\mathrm{N} \text {-terminal }}$, and $\mathrm{Lys}^{17}$-mono-PEGylated rhG-CSF positional isomers were examined by one-way analysis of variance (ANOVA) followed by Dunnett's method for multiple pairwise comparisons. Differences between groups were considered significant when $p$ values were $<0.05$.

\section{RESULTS}

Preparation of Mono-PEGylated rhG-CSF and the Isolation of the $\mathrm{Lys}^{35}$, Met ${ }^{\mathrm{N}-\text { terminal }}$, and Lys ${ }^{17}$-Mono-PEGylated rhG-CSF Positional Isomers As illustrated in Fig. 1, the $\alpha$-amino group of the $\mathrm{N}$-terminal (Met) and the $\varepsilon$-amino groups of lysine residues (Lys ${ }^{17}, \mathrm{Lys}^{24}, \mathrm{Lys}^{35}$, and $\mathrm{Lys}^{41}$ ) in rhG-CSF are potential sites for covalent modification by mPEG-NHS. ${ }^{21)}$ We previously described the preparation of mono-PEGylated rhG-CSF using trimeric-structured mPEG$\mathrm{NHS}^{16)}$ and the structural characterization of individual positional isomers isolated from mono-PEGylated rhG-CSF using a preparative two-step chromatography method developed. The Lys $^{35}$, Met ${ }^{\mathrm{N} \text {-terminal }}$, Lys ${ }^{17}$-mono-PEGylated rhG-CSF positional isomers used in the present in vitro and in vivo pharmacokinetic and pharmacodynamic study had purities $>98 \%$ after size-exclusion chromatography. ${ }^{17)}$

In Vitro Biological Activities of the $\mathrm{Lys}^{35}$, $\mathrm{Met}^{\mathrm{N} \text {-terminal, }}$ and Lys ${ }^{17}$-Mono-PEGylated rhG-CSF Positional Isomers 
The in vitro biological activity of rhG-CSF is commonly determined by cell proliferation assay using the NFS-60 cell line. The in vitro biological activities of the $\mathrm{Lys}^{35}, \mathrm{Met}^{\mathrm{N} \text {-terminal }}$ and $\mathrm{Lys}^{17}$-mono-PEGylated rhG-CSF positional isomers were compared with rhG-CSF $\left(9.5 \times 10^{7} \mathrm{IU} / \mathrm{mg}\right)$ (Table 1). The in vitro biological activities of these isomers were retained at the $20.1 \% \quad\left(1.91 \times 10^{7} \mathrm{IU} / \mathrm{mg}\right), \quad 37.4 \% \quad\left(3.55 \times 10^{7} \mathrm{IU} / \mathrm{mg}\right)$, and $15.3 \%\left(1.45 \times 10^{7} \mathrm{IU} / \mathrm{mg}\right)$ levels, respectively, for the $\mathrm{Lys}^{35}$, $\mathrm{Met}^{\mathrm{N} \text {-terminal }}$, and $\mathrm{Lys}^{17}$-mono-PEGylated rhG-CSF positional isomers versus rhG-CSF. Furthermore, the in vitro biological activities of the three isomers were found to differ signifi-

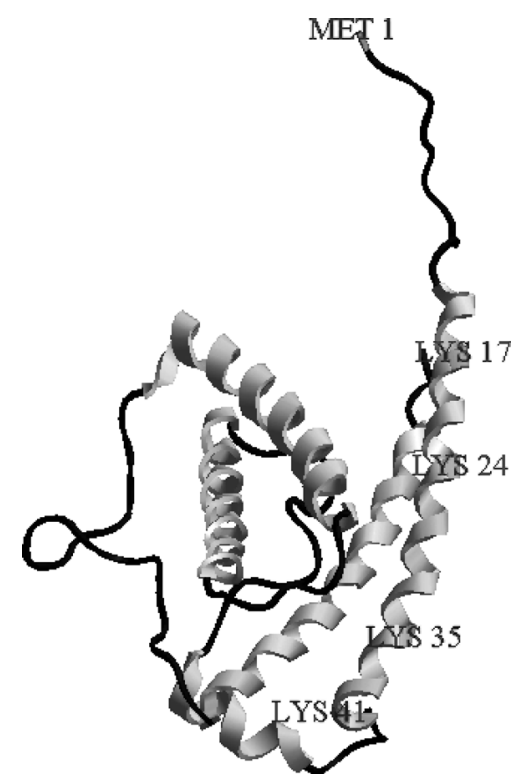

Fig. 1. Ribbon Representation of Three Dimensional (3D) Structure of Recombinant Human Granulocyte-Stimulating Factor (rhG-CSF) and Positions PEGylated

Table 1. In Vitro Biological Activities of the $\mathrm{Lys}^{35}$, $\mathrm{Met}^{\mathrm{N} \text {-terminal }}$, and Lys ${ }^{17}$-Mono-PEGylated rhG-CSF Individual Positional Isomers

\begin{tabular}{|c|c|c|}
\hline Sample & $\begin{array}{l}\text { Biological activity } \\
\quad\left(10^{7} \mathrm{IU} / \mathrm{mg}\right)\end{array}$ & $\begin{array}{c}\text { Relative } \\
\text { activity (\%) }\end{array}$ \\
\hline rhG-CSF & 9.5 & 100 \\
\hline $\begin{array}{l}\text { Lys }^{35} \text {-mono-PEGylated } \\
\text { rhG-CSF }\end{array}$ & $1.91 \pm 0.15$ & $20.1 \pm 1.6^{*, \dagger}$ \\
\hline $\begin{array}{l}\text { Met }^{\text {N-terminal }} \text {-mono-PEGylat- } \\
\text { ed rhG-CSF }\end{array}$ & $3.55 \pm 0.12$ & $37.4 \pm 1.2^{*, \dagger}$ \\
\hline $\begin{array}{l}\text { Lys }^{17} \text {-mono-PEGylated } \\
\text { rhG-CSF }\end{array}$ & $1.45 \pm 0.19$ & $15.3 \pm 2.0^{*, \dagger}$ \\
\hline
\end{tabular}

Relative activity (\%) was defined as residual in vitro biological activity expressed as a percentage of rhG-CSF activity. Results are presented as means \pm S.E.M.s of triplicate experiments. ${ }^{*} p<0.05 v s$. rhG-CSF treated group. ${ }^{\dagger} p<0.05 v s$. each other mono-PEGylated rhG-CSF treated group. cantly.

In Vivo Pharmacokinetics of the $\mathrm{Lys}^{35}, \mathrm{Met}^{\mathrm{N}-\text { terminal }}$, and Lys ${ }^{17}$-Mono-PEGylated rhG-CSF Positional Isomers The pharmacokinetics of the $\mathrm{Lys}^{35}$, Met ${ }^{\mathrm{N}-\text { terminal }}$, and $\mathrm{Lys}^{17}$-monoPEGylated rhG-CSF positional isomers and of rhG-CSF were evaluated in SD rats after a single administration at 0.1 or $0.4 \mathrm{mg} / \mathrm{kg}$ s.c. for the three isomers and $\mathrm{rhG}-\mathrm{CSF}$, respectively. Plasma rhG-CSF concentrations in SD rats following these administrations are shown in Fig. 2, and the pharmacokinetics parameters $\left(C_{\max }, T_{\max }, A U C_{\text {last }}, T_{1 / 2}, M R T_{\text {last }}\right)$ derived by noncompartmental analysis are summarized in Table 2.

All three mono-PEGylated rhG-CSF positional isomers had substantially greater blood half-lives $\left(T_{1 / 2}\right)$ than rhG-CSF, that is, 18.9-21.2 h versus $2.9 \mathrm{~h}$. As illustrated in Fig. 2, the three positional isomers had similar PK profiles. The concentration of rhG-CSF in plasma rapidly increased immediately after administering $0.1 \mathrm{mg} / \mathrm{kg}$ s.c., peaked at $24 \mathrm{~h}\left(T_{\max }\right)$, and then decreased slowly to baseline at $168 \mathrm{~h}$. No significant difference was observed between the $C_{\max }$ and $A U C_{\text {last }}$ values of the three positional isomers. As shown in Table 2, for the Lys ${ }^{35}$, $\mathrm{Met}^{\mathrm{N} \text {-terminal }}$, and $\mathrm{Lys}^{17}$-mono-PEGylated rhG-CSF positional isomers $C_{\max }$ values were $134.7,124.0,119.0 \mathrm{ng} / \mathrm{mL}$, respectively, and $A U C_{\text {last }}$ values were 4535,4450 , and $4495 \mathrm{ng} \cdot \mathrm{h} / \mathrm{mL}$, respectively.

In Vivo Pharmacodynamics of the $\mathrm{Lys}^{35}$, Met ${ }^{\mathrm{N} \text {-terminal, }}$ and Lys $^{17}$-Mono-PEGylated rhG-CSF Positional Isomers Peripheral blood WBC counts and ANC were determined after a single administration of $0.1 \mathrm{mg} / \mathrm{kg}$ (s.c.) of $\mathrm{Lys}^{35}, \mathrm{Met}^{\mathrm{N} \text {-terminal, }}$ or Lys ${ }^{17}$-mono-PEGylated rhG-CSF positional isomers or the daily administration of $0.1 \mathrm{mg} / \mathrm{kg}$ (s.c.) of $\mathrm{rhG}-\mathrm{CSF}$ for $5 \mathrm{~d}$

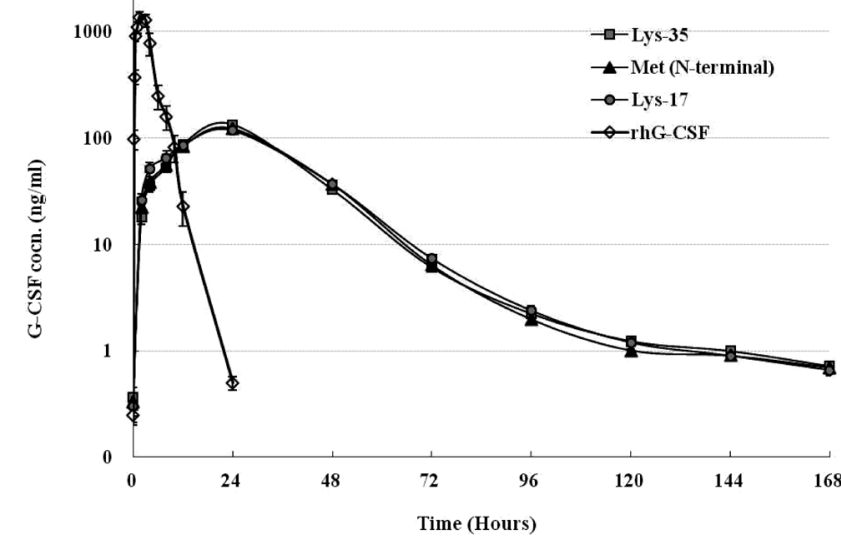

Fig. 2. Plasma rhG-CSF Concentration-Time Profiles after a Single Subcutaneous Injection of the Lys ${ }^{35}$-Mono-PEGylated rhG-CSF ( $\left.\mathbf{\square}\right)$, Met $^{\mathrm{N} \text {-terminal }}$-Mono-PEGylated rhG-CSF $(\boldsymbol{\Delta})$, Lys ${ }^{17}$-Mono-PEGylated rhG$\mathrm{CSF}(\bullet)$, and rhG-CSF $(\diamond)$ in SD Rats

The $\mathrm{Lys}^{35}$, Met ${ }^{\mathrm{N} \text {-terminal }}$, and $\mathrm{Lys}^{17}$ isomers were injected at a dose of $0.1 \mathrm{mg} / \mathrm{kg}$ and $\mathrm{rhG}-\mathrm{CSF}$ at $0.4 \mathrm{mg} / \mathrm{kg}$. Results are expressed as means \pm S.E.M.s.

Table 2. Pharmacokinetic Parameters of $\mathrm{Lys}^{35}, \mathrm{Met}^{\mathrm{N}-\text { terminal }}$, and $\mathrm{Lys}^{17}$-Mono-PEGylated rhG-CSF Individual Positional Isomers in SD Rats

\begin{tabular}{|c|c|c|c|c|c|}
\hline Parameters & $C_{\max }(\mathrm{ng} / \mathrm{mL})$ & $T_{\max }(\mathrm{h})$ & $A U C_{\text {last }}(\mathrm{ng} \cdot \mathrm{h} / \mathrm{mL})$ & $T_{1 / 2}(\mathrm{~h})$ & $M R T_{\text {last }}(\mathrm{h})$ \\
\hline rhG-CSF${ }^{a)}$ & $1383 \pm 243$ & $1.6 \pm 0.7$ & $5643 \pm 306$ & $2.9 \pm 0.1$ & $4.0 \pm 0.1$ \\
\hline Lys $^{35}$-mono-PEGylated rhG-CSF ${ }^{b)}$ & $134.7 \pm 4.3$ & $24.0 \pm 0.0 *$ & $4535 \pm 109$ & $19.1 \pm 0.3 *$ & $28.9 \pm 0.4^{*}$ \\
\hline $\mathrm{Met}^{\mathrm{N}-\text { terminal }}$-mono-PEGylated rhG-CSF${ }^{b)}$ & $124.0 \pm 9.1$ & $24.0 \pm 0.0 *$ & $4450 \pm 227$ & $18.9 \pm 0.2 *$ & $29.3 \pm 0.2 *$ \\
\hline Lys $^{17}$-mono-PEGylated rhG-CSF ${ }^{b)}$ & $119.0 \pm 8.3$ & $24.0 \pm 0.0 *$ & $4495 \pm 220$ & $21.2 \pm 0.7 *$ & $29.4 \pm 0.2 *$ \\
\hline
\end{tabular}

Results are presented as means \pm S.E.M.s. a) The administered dose was $0.4 \mathrm{mg} / \mathrm{kg}$. $b$ ) The administered dose was $0.1 \mathrm{mg} / \mathrm{kg}$. ${ }^{*} p<0.05 v s$. rhG-CSF treated group. 
to SD rats. Both WBC counts and ANC in peripheral blood increased after treatment with the three positional isomers, remained at an elevated level for 1 to $2 \mathrm{~d}$, and then gradually decreased to baseline at $4-5 \mathrm{~d}$. However, 5 daily administrations of $\mathrm{rhG}-\mathrm{CSF}$ at $0.1 \mathrm{mg} / \mathrm{kg} / \mathrm{d}$ s.c. failed to elicit $W B C$ counts and $A N C$ from baseline (Fig. 3). For the $\mathrm{Lys}^{35}$, $\mathrm{Met}^{\mathrm{N} \text {-terminal, }}$ and $\mathrm{Lys}^{17}$-mono-PEGylated rhG-CSF positional isomers peak WBC counts $\left(W B C_{\max }\right)$ were $38.8 \times 10^{9}, 39.5 \times 10^{9}$, and $40.1 \times 10^{9}$ cells/L, respectively, $A U C_{\mathrm{WBC}}$ values were $149.7 \times 10^{9}$, $152.4 \times 10^{9}$ and $156.8 \times 10^{9}$ cells $\cdot \mathrm{d} / \mathrm{L}$, peak $A N C\left(A N C_{\text {max }}\right)$ were $19.8 \times 10^{9}, 21.2 \times 10^{9}$ and $20.5 \times 10^{9}$ cells $/ \mathrm{L}$, and $A U C_{\mathrm{ANC}}$ values were $53.2 \times 10^{9}, 58.5 \times 10^{9}$, and $59.6 \times 10^{9}$ cells $\cdot \mathrm{d} / \mathrm{L}$, respectively. These data show that the three mono-PEGylated rhG-CSF po-
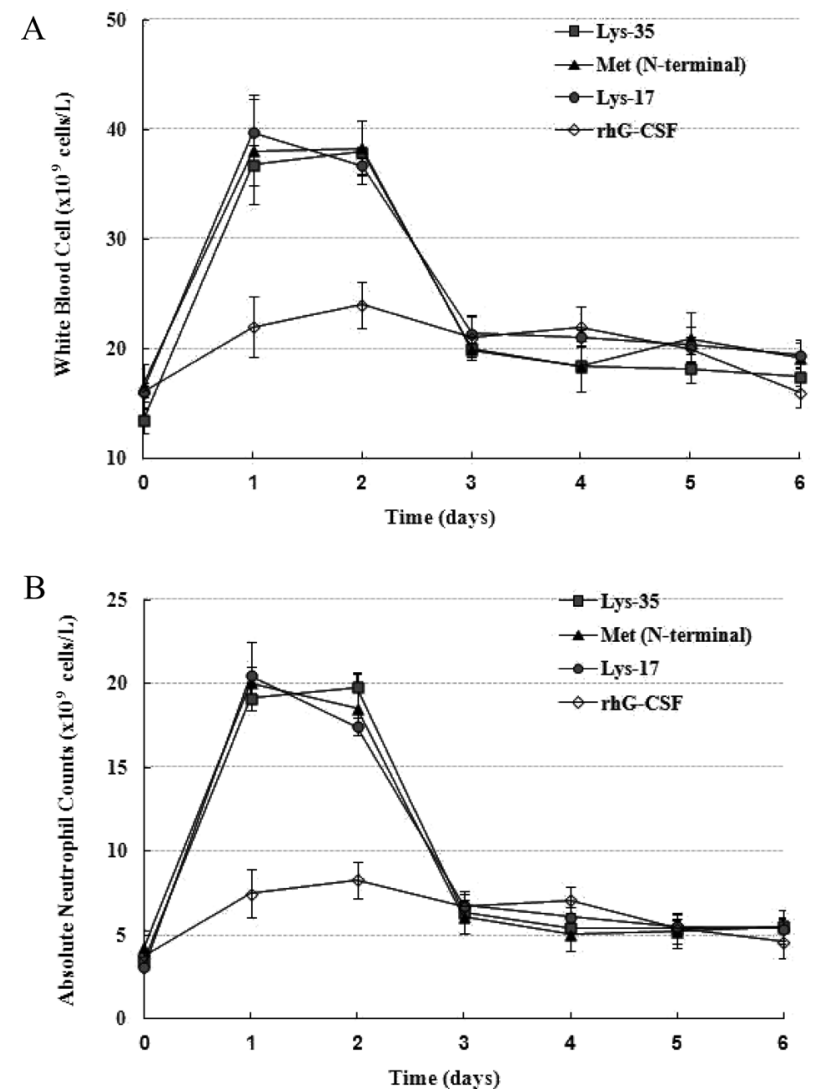

Fig. 3. Total White Blood Cell (WBC) (A) and Absolute Neutrophil Counts (ANC) (B) after a Subcutaneous Injection of $\mathrm{Lys}^{35}$-Mono-

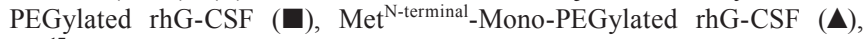
Lys $^{17}$-Mono-PEGylated rhG-CSF $(\bullet)$, or rhG-CSF $(\diamond)$ into SD Rats

$\mathrm{Lys}^{35}, \mathrm{Met}^{\mathrm{N} \text {-terminal }}$, or $\mathrm{Lys}^{17}$ isomers were injected once at $0.1 \mathrm{mg} / \mathrm{kg}$ s.c. and rhG-CSF was injected daily for $5 \mathrm{~d}$ at $0.1 \mathrm{mg} / \mathrm{kg}$ per $\mathrm{d}$. Results are expressed as means \pm S.E.M.s. sitional isomers have similar pharmacodynamic effects.

\section{DISCUSSION}

rhG-CSF is rapidly cleared from circulation by renal clearance and receptor-mediated endocytosis by neutrophils, which result in short-term pharmacological effects. ${ }^{22-24)}$ Conjugation with PEG alters the in vivo efficacies of drugs by altering their pharmacokinetic (PK) and pharmacodynamic (PD) properties. ${ }^{6)}$ Several research groups have shown that the in vivo half-life and activity of rhG-CSF or its mutant can be increase by PEG conjugation using several different conjugation chemistry strategies. ${ }^{9,16,25-31)}$ The results of conjugation between target therapeutic proteins and PEG, such as, the extent of modification, molecular weight, the structure of the PEG moiety (linear or branched), and the locations of PEG attachment, importantly affect in vitro biological activity and pharmacological properties. ${ }^{6,32,33)}$ It has been well established that inverse relationships exist between in vitro biological activity and the average molecular weights of PEG and the number of PEG units, whereas positive relationships exist between in vivo pharmacokinetics and pharmacodynamics and these average molecular weights. ${ }^{34,35)}$ Furthermore, in previous studies, no advantages have been attributed to different conjugation chemistries in the in vivo pharmacokinetics and pharmacodynamics ${ }^{9)}$ whereas selective advantage was attributed to different types of PEG moieties. ${ }^{36)}$

We previously reported on the preparation of monoPEGylated rhG-CSF using $23 \mathrm{kDa}$ trimer-structured methoxy polyethylene glycol with $N$-hydroxy succinimide (mPEGNHS). ${ }^{16)}$

Meanwhile, there has been a growing interest in CMC and in the regulatory aspects of PEG-modified protein drugs. In particular, the structural characterization of individual positional isomers poises significant $\mathrm{CMC}$ challenges concerning the manufacture of PEGylated therapeutic proteins. ${ }^{15)}$ Therefore, in the present study, individual positional isomers were successfully isolated and characterized with respect to site of PEGylation by enzymatic digestion with endoproteinase Lys-C and N-terminal sequencing, which showed that the three positional isomers were PEGylated at $\mathrm{Lys}^{35}$, Met ${ }^{\mathrm{N} \text {-terminal }}$ and $\mathrm{Lys}^{17}$ of rhG-CSF. ${ }^{17)}$ However, no previous report has described the pharmacokinetic and pharmacodynamic properties of positional isomers of PEGylated therapeutic proteins.

In the present study, we evaluated the in vitro biological activities and in vivo pharmacokinetic/pharmacodynamic properties of the $\mathrm{Lys}^{35}$, $\mathrm{Met}^{\mathrm{N} \text {-terminal }}$, and $\mathrm{Lys}^{17}$-mono-PEGylated rhG-CSF positional isomers in SD rats. Animals were

Table 3. Pharmacodynamics Parameters (ANC Levels and WBC Counts) of Lys ${ }^{35}$, Met ${ }^{\mathrm{N} \text {-terminal }}$, and Lys ${ }^{17}$-Mono-PEGylated rhG-CSF Positional Isomers in SD Rats after a Single Administration at $0.1 \mathrm{mg} / \mathrm{kg}$ s.c.

\begin{tabular}{|c|c|c|c|c|}
\hline & \multicolumn{2}{|c|}{ Absolute neutrophil count } & \multicolumn{2}{|c|}{ White blood cell count } \\
\hline & $A N C_{\max }\left(10^{9}\right.$ cells $\left./ \mathrm{L}\right)$ & $A U C_{\mathrm{ANC}}\left(10^{9}\right.$ cells $\left.\cdot \mathrm{d} / \mathrm{L}\right)$ & $W B C_{\max }\left(10^{9}\right.$ cells $\left./ \mathrm{L}\right)$ & $A U C_{\mathrm{WBC}}\left(10^{9}\right.$ cells $\left.\cdot \mathrm{d} / \mathrm{L}\right)$ \\
\hline rhG-CSF & $8.3 \pm 2.4$ & $39.1 \pm 6.5$ & $24.2 \pm 4.6$ & $124.9 \pm 7.3$ \\
\hline Lys $^{35}$-mono-PEGylated rhG-CSF & $19.8 \pm 0.8^{*}$ & $53.2 \pm 7.2 *$ & $38.8 \pm 2.6^{*}$ & $149.7 \pm 2.6^{*}$ \\
\hline $\begin{array}{l}\text { Met }^{\mathrm{N}-\text {-erminal }} \text {-mono-PEGylated } \\
\text { rhG-CSF }\end{array}$ & $21.2 \pm 2.0^{*}$ & $58.5 \pm 4.2 *$ & $39.5 \pm 3.5^{*}$ & $152.4 \pm 14.1 *$ \\
\hline Lys $^{17}$-mono-PEGylated rhG-CSF & $20.5 \pm 2.0^{*}$ & $59.6 \pm 2.0 *$ & $40.1 \pm 3.2 *$ & $156.8 \pm 3.3 *$ \\
\hline
\end{tabular}

$A N C_{\max }=$ maximum observed absolute neutrophil count; $A U C_{\mathrm{ANC}}=$ area under the absolute neutrophil counts $v s$. time curve; $W B C_{\max }=$ maximum observed white blood cell count; $A U C_{\mathrm{WBC}}=$ area under the white blood cell count $v s$. time curve. Results are presented as means \pm S.E.M.s. ${ }^{*} p<0.05 v s$. rhG-CSF treated group. 
administered $0.1 \mathrm{mg} / \mathrm{kg}$ s.c. of the three individual positional isomers in the in vivo pharmacokinetic and pharmacodynamic because mono-PEGylated rhG-CSF exhibited dose-dependent responses in dosage range $10-1000 \mu \mathrm{g} / \mathrm{kg}$ in a preliminary study (data not shown).

The in vitro biological activities of the $\mathrm{Lys}^{35}$, Met ${ }^{\mathrm{N} \text {-terminal }}$, and $\mathrm{Lys}^{17}$-mono-PEGylated rhG-CSF positional isomers in the cell proliferation assay were $20.1 \%\left(1.91 \times 10^{7} \mathrm{IU} / \mathrm{mg}\right), 37.4 \%$ $\left(3.55 \times 10^{7} \mathrm{IU} / \mathrm{mg}\right)$, and $15.3 \%\left(1.45 \times 10^{7} \mathrm{IU} / \mathrm{mg}\right)$, respectively, versus rhG-CSF. In general, the in vitro biological activities of PEGylated proteins are reduced due to steric hindrance caused by PEG at receptors, and the extents of these reductions depend on the extent of PEGylation, and the type (linear or branched) and molecular weight of the PEG used. ${ }^{33-36)}$ Of the three positional isomers examined, the $\mathrm{Met}^{\mathrm{N} \text {-terminal }}$-monoPEGylated rhG-CSF showed the highest in vitro biological activity, which may have been caused by steric hindrance of receptor binding or of active sites on rhG-CSF. It has been reported that $\mathrm{Glu}^{19}$ and $\mathrm{Glu}^{47}$ of G-CSF interact with specific residues in G-CSF receptor. ${ }^{37,38)}$ In addition, the in vitro biological activities of mono-PEGylated rhG-CSF have been reported to be highly dependent on PEG molecular weight ${ }^{34,35)}$ and the number of PEG units attached to rhG-CSF, ${ }^{33)}$ especially in the G-CSF receptor binding region. However, losses of in vitro biological activity shown by the PEGylated rhG-CSF was compensated for by reduced renal clearance due to increased hydrodynamic volume and reduced protease degradation. ${ }^{8,32)}$ It has been well established that the in vitro biological activities of PEGylated proteins decrease with increasing PEG molecular weight $\left(M_{\mathrm{w}}\right)$, but that in vivo activity is enhanced by PEGylation.

The Lys $^{35}$, Met ${ }^{\mathrm{N}-\text { terminal }}$, and $\mathrm{Lys}^{17}$-mono-PEGylated rhGCSF positional isomers showed enhanced pharmacokinetic and pharmacodynamic performance in SD rats (Figs. 2, 3), and as was expected, the three isomers had markedly increased blood half-lives $\left(T_{1 / 2}\right)$ and WBC counts and ANC than rhG-CSF treated rats despite their lower in vitro biological activities. Furthermore, no significant difference was observed between the pharmacokinetic and pharmacodynamic properties of the three isomers. However, their in vitro biological activities were found to depend significantly on PEGylation site (Table 3).

This study demonstrates that the in vivo pharmacokinetics and pharmacodynamics of mono-PEGylated rhG-CSF positional isomers are independent of PEGylation sites for a given PEG moiety, but that their in vitro biological activities are PEGylation site-dependent.

\section{CONCLUSION}

We report for the first time the pharmacokinetics and pharmacodynamics of individual positional isomers of monoPEGylated rhG-CSF. This study demonstrates that $\mathrm{Lys}^{35}$, $\mathrm{Met}^{\mathrm{N} \text {-terminal }}$, and $\mathrm{Lys}^{17}$-mono-PEGylated rhG-CSF positional isomers have different in vitro biological activities but that the in vivo pharmacokinetic and pharmacodynamic properties of the PEGylated rhG-CSF positional isomers are comparable.

Acknowledgment This work was supported by a Grant from the Korea Health Technology R\&D Project, Ministry for Health and Welfare, Republic of Korea (\#A020548).

\section{REFERENCES}

1) Veronese FM, Pasut G. PEGylation, successful approach to drug delivery. Drug Discov. Today, 10, 1451-1458 (2005).

2) Veronese FM, Mero A. The impact of PEGylation on biological therapies. BioDrugs, 22, 315-329 (2008).

3) Harris JM, Martin NE, Modi M. Pegylation: a novel process for modifying pharmacokinetics. Clin. Pharmacokinet., 40, 539-551 (2001).

4) Harris JM, Chess RB. Effect of pegylation on pharmaceuticals. Nat. Rev. Drug Discov., 2, 214-221 (2003).

5) Caliceti P, Veronese FM. Pharmacokinetic and biodistribution properties of poly(ethylene glycol)-protein conjugates. Adv. Drug Deliv. Rev., 55, 1261-1277 (2003).

6) Fishburn CS. The pharmacology of PEGylation: Balancing PD with PK to generate novel therapeutics. J. Pharm. Sci., 97, 4167-4183 (2008).

7) Kang JS, Deluca PP, Lee KC. Emerging PEGylated drugs. Expert Opin. Emerg. Drugs, 14, 363-380 (2009).

8) Jevsevar S, Kunstelj M, Porekar VG. PEGylation of therapeutic proteins. Biotechnol. J., 5, 113-128 (2010).

9) Kinstler OB, Brems DN, Lauren SL, Paige AG, Hamburger JB, Treuheit MJ. Characterization and stability of N-terminally PEGylated rhG-CSF. Pharm. Res., 13, 996-1002 (1996).

10) Wylie DC, Voloch M, Lee SJ, Liu YH, Cannon-Carlson S, Cutler C, Pramanik B. Carboxyalkylated histidine is a $\mathrm{pH}$-dependent product of pegylation with SC-PEG. Pharm. Res., 18, 1354-1360 (2001).

11) Bailon P, Won CY. PEG-modified biopharmaceuticals. Expert Opin. Drug Deliv., 6, 1-16 (2009).

12) Shaunak S, Godwin A, Choi JW, Balan S, Pedone E, Vijayarangam D, Heidelberger S, Teo I, Zloh M, Brocchini S. Site-specific PEGylation of native disulfide bonds in therapeutic proteins. Nat. Chem. Biol., 2, 312-313 (2006).

13) Foser S, Schacher A, Weyer KA, Brugger D, Dietel E, Marti S, Schreitmüller T. Isolation, structural characterization, and antiviral activity of positional isomers of monopegylated interferon $\alpha-2 \mathrm{a}$ (PEGASYS). Protein Expr. Purif., 30, 78-87 (2003).

14) Wang YS, Youngster S, Bausch J, Zhang R, McNemar C, Wyss DF. Identification of the major positional isomer of pegylated interferon alpha-2b. Biochemistry, 39, 10634-10640 (2000).

15) Susan CC, David W, Doug K, Doug I. CMC and regulatory considerations for polyethylene glycol-modified protein therapeutics. Drug Deliv. Syst., 20, 620-634 (2005).

16) Jo YW, Lee MY, Choi YK, Lee SH, Kang SH, Na K, Youn YS, Choi EC. Long-acting recombinant human granulocyte colony stimulating factor (rhG-CSF) with a trimer-structured polyethylene glycol. J. Pharma. Invest., 40, 379-386 (2010).

17) Son JP, Jun SW, Choi YK, Park HS, Son MK, Lee MY, Kang SH, Kang JS, Park YI. Structural identification and biological activity of positional isomers of long-acting and mono-PEGylated recombinant human granulocyte colony-stimulating factor with trimericstructured methoxy polyethylene glycol $N$-hydroxysuccinimidyl functional group. Anal. Biochem., 423, 286-293 (2012).

18) Hara K, Suda T, Suda J, Eguchi M, Ihle JN, Nagata S, Miura Y, Saito M. Bipotential murine hemopoietic cell line (NFS-60) that is responsive to IL-3, GM-CSF, G-CSF, and erythropoietin. Exp. Hematol., 16, 256-261 (1988).

19) Shirafuji N, Asano $S$, Matsuda $S$, Watari $K$, Takaku F, Nagata $S$. A new bioassay for human granulocyte colony-stimulating factor (hG-CSF) using murine myeloblastic NFS-60 cells as targets and estimation of its levels in sera from normal healthy persons and patients with infectious and hematological disorders. Exp. Hematol., 17, 116-119 (1989).

20) Gibaldi M. Biopharmaceutics and clinical pharmacokinetics. 3rd ed., Chapters 3-7, Lea and Febiger, Philadelphia, PA, pp. 17-28 (1984). 
21) Cindrić M, Cepo T, Galić N, Bukvić-Krajacić M, Tomczyk N, Vissers JPC, Bindila L, Peter-Katalinić J. Structural characterization of PEGylated rHuG-CSF and location of PEG attachment sites. $J$. Pharm. Biomed. Anal., 44, 388-395 (2007).

22) Bronchud MH, Potter MR, Morgenstern G, Blasco MJ, Scarffe JH, Thatcher N, Crowther D, Souza LM, Alton NK, Testa NG. In vitro and in vivo analysis of the effects of recombinant human granulocyte colony-stimulating factor in patients. Br. J. Cancer, 58, 64-69 (1988).

23) Tanaka H, Okada Y, Kawagishi M, Tokiwa T. Pharmacokinetics and pharmacodynamics of recombinant human granulocyte-colony stimulating factor after intravenous and subcutaneous administration in the rat. J. Pharmacol. Exp. Ther., 251, 1199-1203 (1989).

24) Frampton JE, Lee CR, Faulds D. Filgrastim. A review of its pharmacological properties and therapeutic efficacy in neutropenia. Drugs, 48, 731-760 (1994).

25) Tanaka H, Satake-Ishikawa R, Ishikawa M, Matsuki S, Asano K. Pharmacokinetics of recombinant human granulocyte colony-stimulating factor conjugated to polyethylene glycol in rats. Cancer Res., 51, 3710-3714 (1991).

26) Satake-Ishikawa R, Ishikawa M, Okada $Y$, Kakitani M, Kawagishi M, Matsuki S, Asano K. Chemical modification of recombinant human granulocyte colony-stimulating factor by polyethylene glycol increases its biological activity in vivo. Cell Struct. Funct., 17, 157-160 (1992)

27) Yamasaki M, Asano M, Okabe M, Morimoto M, Yokoo Y. Modification of recombinant human granulocyte colony-stimulating factor (rhG-CSF) and its derivative ND 28 with polyethylene glycol. $J$. Biochem., 115, 814-819 (1994).

28) Molineux G, Kinstler OB, Briddell B, Hartley C, McElroy P, Kerzic P, Sutherland W, Stoney G, Kern B, Fletcher FA, Cohen A, Korach E, Ulich T, McNiece I, Lockbaum P, Miller-Messana MA, Gardner S, Hunt T, Schwab G. A new form of Filgrastim with sustained duration in vivo and enhanced ability to mobilize PBPC in both mice and humans. Exp. Hematol., 27, 1724-1734 (1999).
29) Lord BI, Woolford LB, Molineux G. Kinetics of neutrophil production in normal and neutropenic animals during the response to filgrastim (r-metHu G-CSF) or filgrastim SD/01 (PEG-r-metHu G-CSF). Clin. Cancer Res., 7, 2085-2090 (2001).

30) Yang BB, Lum PK, Hayashi MM, Roskos LK. Polyethylene glycol modification of filgrastim results in decreased renal clearance of the protein in rats. J. Pharm. Sci., 93, 1367-1373 (2004).

31) Molineux G. The design and development of pegfilgrastim (PEGrmetHuG-CSF, Neulasta). Curr. Pharm. Des., 10, 1235-1244 (2004).

32) Roberts MJ, Bentley MD, Harris JM. Chemistry for peptide and protein PEGylation. Adv. Drug Deliv. Rev., 54, 459-476 (2002).

33) Yamasaki M, Asano M, Yokoo Y, Okabe M. Effect of divalent polyethylene glycol units, conjugated on human granulocyte colonystimulating factor, on biological activities in vitro and in vivo. Drugs Exp. Clin. Res., 24, 191-196 (1998).

34) Bowen S, Tare N, Inoue T, Yamasaki M, Okabe M, Horii I, Eliason JF. Relationship between molecular mass and duration of activity of polyethylene glycol conjugated granulocyte colony-stimulating factor mutein. Exp. Hematol., 27, 425-432 (1999).

35) Zhai Y, Zhao Y, Lei J, Su Z, Ma G. Enhanced circulation half-life of site-specific PEGylated rhG-CSF: optimization of PEG molecular weight. J. Biotechnol., 142, 259-266 (2009).

36) Li XQ, Lei JD, Su ZG, Ma GH. Comparison of bioactivities of monoPEGylated rhG-CSF with branched and linear mPEG. Process Biochem., 42, 1625-1631 (2007).

37) Layton JE, Shimamoto G, Osslund T, Hammacher A, Smith DK, Treutlein HR, Boone T. Interaction of granulocyte colonystimulating factor (G-CSF) with its receptor. Evidence that $\mathrm{Glu}^{19}$ of G-CSF interacts with $\mathrm{Arg}^{288}$ of the receptor. J. Biol. Chem., 274, 17445-17451 (1999).

38) Kotto-Kome AC, Fox SE, Lu W, Yang B-B, Christensen RD, Calhoun DA. Evidence that the granulocyte colony-stimulating factor (G-CSF) receptor plays a role in the pharmacokinetics of G-CSF and PegG-CSF using a G-CSF-RKO model. Pharmacol. Res., 50, 55-58 (2004). 